This item was submitted to Loughborough's Research Repository by the author.

Items in Figshare are protected by copyright, with all rights reserved, unless otherwise indicated.

\title{
Interactive digital books and interpretive play
}

PLEASE CITE THE PUBLISHED VERSION

https://doi.org/10.1163/9789004468337_007

PUBLISHER

Brill

VERSION

AM (Accepted Manuscript)

PUBLISHER STATEMENT

This book chapter was published in the book Reproducing Images and Texts [@ Koninklijke Brill]. The publisher's website is at https://doi.org/10.1163/9789004468337_007

\section{LICENCE}

CC BY-NC-ND 4.0

\section{REPOSITORY RECORD}

Brown, Kathryn. 2021. "Interactive Digital Books and Interpretive Play”. Loughborough University. https://hdl.handle.net/2134/14222528.v1. 


\title{
Interactive Digital Books and Interpretive Play
}

\author{
Kathryn Brown
}

In his essay “Les deux vertus d'un livre," Paul Valéry contrasts two reading experiences: the linear, visual appropriation of text and the reader's "immediate and simultaneous" confrontation with the composition and typography of the page. The text "read" and the text "seen" are, he argues, distinct aspects of the phenomenology of reading (Valéry 124647). The contrast identified by Valéry is heightened in the transition from print to screenbased culture. If, as Valéry suggests, the reader's appreciation of a book's material qualities consists in a series of "stationary impressions," interactive works exploit the creative potential of seriality by inviting the reader to explore different iterations of a book's visible content. This article will argue that such repeated engagement is key to appreciating the aesthetic content of interactive digital books: as a reader experiences the work, he or she is also aware of its other possible realizations, alternative textual manifestations, and diverse visual forms. In consequence, the act of reading becomes an essentially open practice in which meaning is created from a work's multiple recombinations. In this case, therefore, digital books are associated with visual and syntactic variation rather than the reproduction of stable textual forms.

Focusing on a range of digital works including installations, programs for desktop computers, and apps for handheld mobile devices, this article will debate tensions between the experience of text on screen and paper in order to distinguish the significance of "playing" with works in electronic media. Rather than considering digital books as dematerializations of the traditional codex, I shall show how such works extend certain aspects of European book history and engage the reader's body for the purpose of expanding the range of "performances" that can be generated by a text. 


\section{Screen-Based Books and Print Traditions}

In his contribution to an essay collection titled The Murder of Books, Jean-Luc Coudray argues that a digital book is not a book. It is, he suggests, the image of a book, a simulacrum of the physical world that is "imprisoned" in a computer environment and is, therefore, parasitical on the "classical" codex (Coudray 53). Coudray's discussion is typical of a line of criticism that understands the category "book" as comprising a set of necessary and sufficient conditions derived from traditional engagement with a paper object. His notion of the digital book as a "parasite" is a powerful metaphor of the way in which electronic works might be said to prey upon the physical environment, but it can also be understood in a literal sense. Coudray imagines the reader as inhabiting a world of tangible things, whereas digital books are confined to a virtual space (a "para-site") that sits apart from that world.

Coudray's account is part of a broader discourse of anxiety concerning the potential erosion of traditional book culture by digital artefacts. ${ }^{1}$ Yet as Andrea Ballatore and Simone Natale have noted, "prophecies about the possible disappearance of an old medium as a consequence of the introduction of a new one have often shaped debates about technology, innovation and their impact on society and culture" (Ballatore and Natale 2380). While the threat posed by digital books to the cultural role of the codex has been a potent part of twenty-first century book rhetoric, competition between virtual and physical realms has also been understood by some writers and artists as a spur to creativity and a means of identifying the potential of works in electronic media.

In 1990 (now considered the early history of computer art forms), artist and scholar Craig Hickman commented on "the computer's seductive mimetic genius" when describing the production of one of his own artist's books (Hickman 278). Writing in a similar vein in 
1997, Jacquelyn A. Martino spoke of her attempt to create "the digital, animated equivalent of paper" (Martino 12). She cited one advantage of such an approach as meeting the audience's need for clarity of use: the "handmade book" functions as a "controlling vehicle" for interaction and can, therefore, be quickly accessed and mastered by the user (12). In the same year, Johanna Drucker reflected on the "simulacral phantoms" that characterize this branch of digital creativity, noting how human habits and memories can impose sense on abstract data (Drucker 109). Taking up a term proposed by George Lakoff and Mark Johnson in Metaphors We Live By, in these cases metaphors of the codex create "cultural coherence" between physical and virtual worlds and determine a set of practices against which to measure the reader's engagement with works in electronic media (Lakoff and Johnson 22-24). As such they provide an important counterweight to the binary oppositions between physical and virtual that have driven many apocalyptic predictions about the demise of the book. ${ }^{2}$

One potent vein of metaphoric language that is tested in the shift from paper to digital books relates to the human body. Gretchen E. Henderson and Amaranth Borsuk point out that many book metaphors in the European tradition transpose images of the body to the codex: books have "spines;" some of them have an "appendix;" pages have "headers" and "footers" (Henderson 31; Borsuk, The Book 77). Complementing this emphasis on corporeality, historians have focused on ways in books (particularly luxury editions) have often been eroticized as women (Melot 186-91). Although women were typically viewed as the enemies of luxury books within European bibliophile circles, metaphors of the female body appear regularly in the rhetoric of book collecting throughout the nineteenth and early twentieth centuries (Silverman 18). For Stéphane Mallarmé writing in 1895, it was only when the paper knife was introduced into the "virgin" pages of the book that the reader truly took possession of it (Mallarmé 227). As Évanghélia Stead has noted, it was small wonder that for many heterosexual male readers, the idea of "curling up" with a good 
book - the pages of which one could "fondle" or "caress" — evoked pleasures beyond the merely literary (Stead 231-68).

The question arises as to whether books in electronic media reinforce or challenge these bodily metaphors. If the historical emphasis on physicality suggests different acts of taking possession, can one ever truly possess a digital artefact? In The Art of the Publisher, Roberto Calasso is dismissive of the electronic format:

The tablet, or whatever other device, has to guarantee that everything is obtainable (literally, in that it can be summoned at a single touch). But not just that: it must also happen inside a minimum number of square centimeters. The device thus tends to become a two-dimensional shadow brain that has none of the mucilaginous consistency of the human brain. (Calasso 120)

Calasso views the software that powers the digital book as antithetical to the "wetware" that powers the reader's mind. In his account, the decorporealized digital object is efficient in terms of the information it carries, but sensorily disappointing for the reader. In a similar vein, Gretchen E. Henderson argues that digital artefacts lack the viscosity of their "dirty" or "sticky" physical counterparts (Henderson 30). In these cases, bodily metaphors appear once again, but only to distinguish human from android, codex from e-book. If physical books grow old like their readers, digital books simply become obsolete.

The latter problem is acute in the case of screen-based books. Such works are not self-sufficient, but require a power source as well as correct, up-to-date hardware and software in order to function correctly. Devoid of a stable physical container, can digital books be "reproduced," "owned," "collected," and "shelved" in a lasting fashionparticularly as cloud-based computing comes increasingly to dominate the use of portable devices? In debating these issues, Naomi Baron turns to another physical metaphor in her suggestion that the major difference between traditional books and electronic books "is whether their innards are physically at hand or whether they remain buried out of sight" (Baron 133). In Baron's account, the reader has access to the "guts" of a physical book, 
whereas digital books maintain a discreet veil over their workings. The latter do not offer a standing invitation for use because their interior remains permanently hidden and contingent on a power source other than the mind of the reader.

It is important to be wary, however, of the extent to which such bodily metaphors might obscure the empirical qualities of digital objects and, indeed, overlook important ways in which such works do actually engage the reader's body. ${ }^{3}$ Many digital books require animation by the reader, but in ways that differ from the visual experience of typeface or the physical act of page-turning. The remainder of this article will be concerned with ways in which digital books develop some of the physical metaphors associated with print books and how, in turn, this links to the reader's enjoyment of repeated textual play.

\section{Repeated Reading and Textual Play}

In the online description of their book Between Page and Screen (2012), Amaranth Borsuk and Brad Bouse describe their aim of exploring "the place of books as objects in an era of increasingly screen-based reading" (Borsuk and Bouse). Although this paper-based work has the format of the familiar codex, its pages comprise abstract symbols that appear to be illegible. In order to read one of symbols, the user must hold the page in front of a webcam which decodes the content. Only at that point are the abstract markings translated into legible words. Rather than reinforcing a contrast between the physical and the technological, the work prompts a fusion of the reader's body with the computer screen: pages need to be opened, manipulated, and held, but the initial act of reading (and translation) is undertaken by a machine. In this new state of co-dependence, the real and the virtual are finely balanced, and reading is delegated, in the first instance, to the mechanical eye of the computer. Not an "interactive" work as such, Between Page and Screen might be 
best described as ushering in a "co-operative" reading model where machine and human employ their own mechanisms of decoding to produce a range of textual outcomes.

A more immersive physical experience within a digital text-world takes places in Text Rain by Romy Achituv and Camille Utterback (1999). In this work, individuals use their entire bodies to catch and play with descending words that form lines of poetry around their limbs projected onto screens in front of them. As the authors point out in their web commentary, the set-up of the work transforms reading into a physical experience that extends beyond the merely visual: "'Reading' the phrases in the Text Rain installation becomes a physical as well as a cerebral endeavour" (Utterback). Eschewing notions of textual reproduction, each iteration of the work becomes a physical game in which participants use their bodies to produce different visual patterns and poems. Far from making the human body redundant, this dematerialized book redirects the reader's visual appropriation of language into a gestural world in which individual letters are caught, thrown, and juggled. This kind of physical interaction with a moving text has become a standard trope for digital works produced over the past twenty years. Rafael LozanoHemmer's Airborne Series (2015), for example, employs a "heat map" of the viewer's body for the purpose of animating literary, scientific, and philosophical texts, and his Re:positioning Fear: Relational Architecture 3 (1997) used projected shadows of the reader's body to reveal online debates about migration (fig. 1). ${ }^{4}$

Could digital works of this kind be described as "books" even though they have no identifiable "containers"? Arguably, they pursue clear analogies with the printed page of the codex. Text Rain, for example, might be understood as an animated, digital calligram. It is as if the reader had walked into Guillaume Apollinaire's poem "Il pleut" (1914) to find the words actually descending around his or her body (Apollinaire 203). Similarly, it is possible to conceive of both Text Rain and Lozano-Hemmer's Airborne series as pages that seek a form of binding. Contemporary artist Keith Smith has suggested that bookbinding is 
not simply the creation of a physical container, but rather a means by which an identifiable order is imposed on time and space (Smith 54-64). In the digital works discussed above, the human body might be said to perform a similar function by serving as a sense-making device that controls and orders the text. No longer a metaphor of the book, in these cases the body is the book.

Digital texts packaged as apps for mobile devices may be said to have more definite material "containers" and thereby to exploit forms that are closer to the physical codex. In the following discussion, I shall consider how a selection of text-based apps engage the body and invite repeated reading that is akin to gaming. Consideration of these works will illuminate ways in which the body remains a key reference point in structuring invitations to play with, and produce meaning from, digital books.

The first example is Tom Phillips's A Humument (A Treated Victorian Novel), a book on which the artist began work in $1966 .{ }^{5}$ The author drew on, painted, and collaged over the pages of this text for fifty years to produce a series of differently "treated books." Just as Text Rain includes letters that fall into different sequences, so too A Humument makes use of visible gutters through the typeface on its pages to create ad hoc poems overlaid by stunning imagery. In 2010 Phillips launched a digital version of the book with its own app that, in some measure, reproduced the print version. The pages of the electronic work could be turned in the manner of a conventional codex, but the author added a feature that made the work more germane to its digital environment: an interactive "Oracle Function". The user of the app was told that:

It is the book's inherent Delphic properties which have inspired its interactive use as an oracle. By casting the pages, and by reading them in tandem you may receive direction, truth, encouragement or warning. There is amusement in the game but watch out for the odd uncanny prophecy and the occasional sharper shaft of truth. ${ }^{6}$ 
Within the Oracle Function, the user could choose a date, spin a virtual wheel, and ask for a prophecy. The result was the random fusion of two digital pages to produce an ad hoc poem. It debatable whether this feature added conceptually to Phillips's book insofar as it repeated the spontaneous process of poetic creation found on the altered pages themselves. Essentially, the oracle function imported an element of interactivity that participants in the digital environment have come to expect from computer art forms.

Phillips's addition of this element to the book did, however, raise a question about the object of the reader's aesthetic interest in a work of this kind. In an interactive digital book, the reader's attention is pulled between text, image, the experience of play, and the design of the software program. This point comes to the fore in the digital poetry book, $A B R A$, an online artists' book with a shifting text created by Amaranth Borsuk, Kate Durbin, and Ian Hatcher (2015). The app (designed for iPhone and iPad) offers an array of words that can be "pruned", "grafted", "erased", and substituted according to the reader's preferences and the chance recombination of elements. Poems are formed from the words following the reader's swipe of the screen. The title of the work is the first half of the spell "abracadabra", and its ambition is described in the following terms:

The Abra app is a poetry instrument/spellbook that responds to touch. Caress the words and watch them shift under your fingers. [...] There are many ways to interact with Abra. Read, write, and experiment to discover Abra's secrets and make her poems your own.

This app is designed to be at once a book, a toy, an instrument, and a tool for writing poetry. You can learn how it works by playing. (Borsuk et al., Abra "Introduction")

This rhetoric extends traditions associated with the codex as discussed above. Reviving familiar bibliophile points of reference, this book-cum-app is gendered as female and the reader is invited to enjoy the seduction of its tactile qualities. Like the digital version of $A$ Humument, the work is described as an interactive game that invites an experience of play consisting in the production of visibly different pages. 
A related, but less interactive, style of mutability occurs in the multi-author e-book, Lost in Track Changes (Capp et al. 2015). Published in 2015, this work is written by five authors who use track changes to alter each other's texts. The reader has access to the original texts and their alternate versions, each showing the level of change made by the other writers. In this case, textual reproduction is visible, but made subject to a digital "remix". The preface claims that the result is a uniquely modern art, "storytelling born of the digital age" (Groth 4). It is worth asking, however, whether the underlying premise of this work and those discussed above are, in fact, determined by features that are germane only to the digital environment?

Although they harness new technologies, these works use concepts that have been fundamental to ways in which artists and writers have long conceived of the expressive potential of books and poetic texts. The essential premise of Abra is, for example, reminiscent of Tristan Tzara's instructions on how to write a Dada poem-essentially the chance patterns formed by recasting miscellaneous words cut from a newspaper (Tzara 302). Both A Humument and Lost in Track Changes exploit different forms of textual contingency, but these are not new. They put into action a poetic found in Mallarmé’s “Un coup de dés" (1897), a work that invites multiple readings through its innovative typography and page layout. As Anna Sigrídur Arnar has pointed out, Mallarmé conceived of the ideal book as an interactive "game, a set of 'combinatorial' possibilities in which the reader plays an active role and that pre-figure textual play in our digital world" (Arnar 289). Even the magical premise of Abra or A Humument evokes the book of occult magic (the "grimoire"), a popular book metaphor in Symbolist circles of the late nineteenth century (155-56).

If interactive digital texts rely on notions of contingency, play, and recombination that are, in fact, familiar elements of book history, is there anything distinctive about their transposition to the digital environment? Answering that question in the affirmative, I 
suggest that probing this question helps to identify the object of aesthetic interest in these screen-based works. Much recent scholarship on computer art forms has focused on themes of gaming, role-playing, and interactivity. ${ }^{7}$ In the case of digital books, the question arises as to whether playing a textual game involving the recombination of words and images undermines the reader's interest in, and appreciation of, the text itself? In such a case, does the text risk degenerating into a "pretext" for the game? In his discussion of the ontology of computer art, Dominic McIver Lopes offers a view that preserves the aesthetic relevance of multiple elements of an interactive work in an electronic medium:

The user generates displays of a work. She also attends to her generating a display of the work as part of trying to appreciate both the display and the work itself. The display and the work are twofold objects of appreciative attention. [...] The more she interacts, the richer her sense of the work and its possibilities. (Lopes 94)

For Lopes, in addition to any visual, textual, or design qualities of an interactive computer artwork, the user's repeated generation of, and engagement with, changing displays on screen is a legitimate part of his or her aesthetic interest in the work as a whole. Indeed, the user's appreciation of the work is deepened, Lopes argues, by acts of replaying: "repetition interspersed with reflecting on the significance of the differences between interactions" enhances appreciation of the work (92).

Lopes's argument is helpful in the context of interactive digital books for it highlights the importance of re-reading — or repeatedly "playing"—such works. In this case, repetition is an activity that enables the reader to enjoy the software program and the visible difference between screen images, as much as the text and its different manifestations from time to time. The more often readers employ the Oracle function of $A$ Humument, read with and though the mark and overstrike in Lost in Track Changes, or graft, erase, and substitute words in Abra, the greater their appreciation of the differences between each instantiation of the work and, hence, of the digital book as a whole. 
As discussed above, this style of discontinuous textual play has familiar antecedents in book history. Without undermining the role played by those antecedents, I suggest that digital artists books should be understood as generating performative "events," namely, repeated instantiations of a work in which audiences read vertically as well as horizontally. By reading "vertically" I mean reading into alternative versions of the text and, crucially, into its different visible manifestations. ${ }^{8}$ In this case, writing and coding can be understood as the creation of scores for a range of unique "performances" by the reader. Returning to Valéry's comments with which I began this chapter, the reader of an interactive digital book is confronted by, and invited to delight in, a range of "immediate and simultaneous" impressions of pages that shift, fracture, and recombine according to the way in which they are played. The reader's awareness of all of those possibilities (whether realized or not) informs appreciation of the work.

By understanding interactive digital books in this way, metaphors associated with the "thingness" of the codex become less salient markers against which to identify and define the parameters of works in electronic media. Instead, equal weight may be given to the textual content of the work and the playability of its software. This view also permits a reconceptualization of the functionality of books that are experienced in computer environments. Rather than viewing reroutings, blocked access messages, and error codes as failures, these can be accepted as contributions to digital books' unique performances from time to time and the means by which those works (and the reader's experience of them) elude reproduction. As such, the limited lifespans of digital books identify them within a new genre of textual, visual, and electronic ephemera.

There is, however, one important factor that is consistent in this transition from print to electronic book, and that is the involvement of the reader's body. For this reason, I would add to Lopes's argument that computer art works are "twofold objects of appreciative attention" (Lopes 94). Rather, I suggest that interactive digital books are 
threefold objects of attention: the reader attends to the content of the work, to changes in its display from time to time, and to the kind of physical engagement that it demands. From the stimulation of aural and visual responses, to the manipulation of hardware, and the employment of strokes, caresses, swipes, and gestures, innovative reading technologies induce new bodily responses to language, hardware, and software. Far from diminishing physical engagement, the dematerialization of the codex is paired with enhanced corporeal self-awareness on the part of the reader. Indeed, as Amaranth Borsuk argues, it is only when the bodies belonging to both text and reader come together "that a book takes shape" (Borsuk, The Book 258). This view posits a symbiotic relationship from which books (in whatever form) emerge as a result of physical interaction between a text and its audiences from time to time - a point that, as I have argued, comes to the fore dramatically in the case of digital works.

Roger Chartier has argued that reading is not "an abstract operation of the intellect it brings the body into play, it is inscribed in a space and a relationship with oneself or with others" (Chartier 8-9). Reading never simply entails a visual engagement with a text, but determines the reader's momentary relationship to the world and the position of the individual's body within it. While this leads Chartier to retrace historical reading habits, I would add that it also encourages a reconception of bodily interactions with texts in digital format. From printed page to screen-based code, from reader to player, our repeated engagement with interactive digital books expands our range of textual performances and enables us to reconceive the ways in which we navigate the world both linguistically and sensorily.

\footnotetext{
${ }^{1}$ For further discussion on this and the aesthetic of electronic books see: Marc Perelman, "Livre papier vs livre électronique (forme chaude vs forme froide)," In L'esthétique du livre, ed., Alain Milon and Marc Perelman, Paris: PU Paris Ouest, 2010, 397-409; Cédric Biagini, L'Assassinat des livres par ceux qui æuvrent à la dématérialisation du monde, Paris: Éditions L’Échappée, 2015; Naomi Baron, Words Onscreen: The Fate of Reading in a Digital World, Oxford: Oxford UP, 2015.
} 


\footnotetext{
${ }^{2}$ Such comparisons raise the question as to whether pursuing a binary opposition between paper and electronic books is conceptually helpful (Hayles and Pressman ix).

${ }^{3}$ Drucker notes that works in electronic media are only "immaterial" by virtue of their comparison to extant media and that comparisons risk overlooking "the specific materiality of the electronic form" (Drucker 96).

${ }^{4}$ For details of these projects see Rafael Lozano-Hemmer's website: http://www.lozano-hemmer.com/ [accessed 14 December 2017].

${ }^{5}$ See the artist's discussion of the background to this work at http://www.tomphillips.co.uk/humument [accessed 14 December 2017].

${ }^{6}$ Tom Phillips, A Humument App, version 1.06. [accessed 3 July 2017].

${ }^{7}$ See, for example, Katja Kwastek, The Aesthetics of Interaction in Digital Art, Trans., Niamh Warde, Cambridge MA: MIT Press, 2013, 71-811; David J. Getsy, ed., From Diversion to Subversion: Games, Play, and Twentieth-Century Art, University Park, Pennsylvania: Penn State UP, 2011; Amaranth Borsuk, The Book, Cambridge, Mass.: MIT Press, 2018, 247.

${ }^{8}$ In her discussion of the relationship between print and digital book cultures, Amaranth Borsuk examines spatiality and "looking through" the pages of "recombinant books", slot books, pop-up books, and tunnel books (Borsuk, The Book 149 and 178).
}

\section{Sources Cited}

Apollinaire, Guillaume. Euvres poétiques. Ed. Marcel Adéma and Michel Décaudin. Paris: Gallimard, Bibliothèque de la Pléiade, 1965.

Arnar, Anna Sigrídur. The Book as Instrument: Stéphane Mallarmé, the Artist's Book, and the Transformation of Print Culture. Chicago: Chicago UP, 2011.

Ballatore, Andrea and Simone Natale. "E-readers and the death of the book: Or, new media and the myth of the disappearing medium". New Media \& Society. 18.10 (2015): 237994.

Baron, Naomi. Words Onscreen: The Fate of Reading in a Digital World. Oxford: Oxford UP, 2015.

Biagini, Cédric, ed. L'Assassinat des livres par ceux qui œuvrent à la dématérialisation du monde. Paris: Éditions L'Échappée, 2015.

Borsuk, Amaranth. The Book. Cambridge, Mass.: MIT Press, 2018.

Borsuk, Amaranth and Brad Bouse. Between Page and Screen. $2^{\text {nd }}$ edition. New York: Siglio, 2012. http://www.betweenpageandscreen.com/ [accessed 4 December 2017].

Borsuk, Amaranth, Kate Durbin, and Ian Hatcher. Abra. http://www.a-b-r-a.com/ [accessed 5 December 2017].

Calasso, Roberto. The Art of the Publisher. Trans. Richard Dixon. London: Penguin, 2015.

Capp, Fiona, Robert Hoge, Cate Kennedy, Krissy Kneen, Ryan O’Neill, Emily Craven, Omar Sakr. Designed by Megan Hoogenboom. Lost in Track Changes. Brisbane: if:book, 2015. http://www.betweenpageandscreen.com/about [accessed 11 December 2017]. 
Chartier, Roger. The Order of Books: Readers, Authors, and Libraries in Europe between the Fourteenth and Eighteenth Centuries. Trans. Lydia G. Cochrane. Stanford: Stanford UP, 1994.

Coudray, Jean-Luc. “Le Livre numérique n'est pas un livre.” In L'Assassinat des livres par ceux qui ouvrent à la dématérialisation du monde. Ed. Cédric Biagini. Paris: Éditions L’Échappée, 2015. 53-57.

Drucker, Johanna. "The Self-Conscious Codex: Artists' Books and Electronic Media." SubStance. 26.1 (1997): 93-112.

Getsy, David J., ed. From Diversion to Subversion: Games, Play, and Twentieth-Century Art. University Park, Pennsylvania: Penn State UP, 2011.

Groth, Simon. "Preface.” In Lost in Track Changes. Fiona Capp et al. Brisbane: if:book, 2015.

Hayles, N. Katherine and Jessica Pressman, ed. Comparative Textual Media: Transforming the Humanities in a Postprint Era. Minneapolis: U of Minnesota P, 2013.

Henderson, Gretchen E. “This is not a Book: Melting Across Bounds.” Journal of Artists Books. 33 (Spring 2013): 29-33.

Hickman, Craig. "Signal to Noise: A Computer-Based Artist's Book." Art Journal. 49.3 (1990): 278-82.

Kaenel, Philippe. "De la bibliophilie au livre d'artiste numérique: conceptions et confusions.” Revue française d'histoire du livre 36 (2015): 207-24.

Kwastek, Katja. Aesthetics of Interaction in Digital Art. Trans. Niamh Warde. Cambridge, Mass.: MIT Press, 2013.

Lakoff, George and Mark Johnson. Metaphors We Live By. Chicago: U of Chicago P, 2003.

Lopes, Dominic McIver. A Philosophy of Computer Art. London and New York: Routledge, 2010.

Lozano-Hemmer, Rafael. http://www.lozano-hemmer.com/ [accessed 14 December 2017].

Mallarmé, Stéphane. Euvres complètes. Vol. II. Ed. Bertrand Marchal. Paris: Gallimard, Bibliothèque de la Pléiade, 2003.

Martino, Jacquelyn A. “'Without a Special Object of Worship': An Interactive Book-Arts Computer Installation.” Leonardo. 30.1 (1997): 11-18.

Melot, Michel. Livre. Paris: L'œil neuf, 2006.

Philips, Tom. http://www.tomphillips.co.uk/. [accessed 14 December 2017].

Silverman, Willa Z. The New Bibliopolis: French Book Collectors and the Culture of Print 1880-1914. Toronto: U of Toronto P, 2008. 
Smith, Keith. "The Book as Physical Object." In A Book of the Book: Some Works and Projections About the Book and Writing. Ed. Jerome Rothenbeg and Steven Clay. New York: Granary Books, 2000. 54-70.

Stead, Évanghélia. La Chair du livre: Matérialité, imaginaire et poétique du livre fin-desiècle. Paris: PU Paris-Sorbonne, 2012.

Tzara, Tristan. "Dada manifeste sur l'amour faible et l'amour amer" [1920-21]. In Poésies complètes. Ed. Henri Béhar. Paris: Flammarion, 2011. 297-307.

Utterback, Camille. http://camilleutterback.com/ [accessed 4 December 2017].

---. Text Rain. http://camilleutterback.com/projects/text-rain/ [accessed 14 December 2017].

Valéry, Paul. Euvres. Vol. II. Ed. Jean Hytier. Paris: Gallimard, Bibliothèque de la Pléiade, 1960. 